\title{
Financial Inclusion in Rwanda: Achievements, Challenges and Prospectives. Evidence from Umurenge Saccos
}

\author{
Uzziel Hategekimana $^{1 *}$; Prof. Thomas R. Kigabo ${ }^{2}$ and Dr. Charles Ruhara ${ }^{3}$ \\ ${ }^{1}$ Lecturer of Finance and Accounting at University of Rwanda, College of Business and Economics \\ (UR-CBE) (Kigali-Rwanda) \\ ${ }^{2}$ Chief Economist at National Bank of Rwanda (BNR) Kigali-Rwanda
}

${ }^{3}$ Senior Lecturer of Economics at University of Rwanda, College of Business and Economics (URCBE)

\begin{abstract}
Financial inclusion has become a major concern to policy makers at both national and global levels, in the aspect of achieving sustainable economic development. To achieve desirable level of financial inclusion, Government of Rwanda established a community based financial institution under designation of "UMURENGE SACCO". The study sought to examine the extent at which UMURENGE SACCOs contributed in achieving accessibility, affordability and uptake of financial services in Rwanda. The study adopted a triangulation of quantitative and qualitative research approach. Data from demand side of financial inclusion was collected using questionnaire and documentary review. Population under study was 55898 members of 10 selected UMURENGE SACCOs throughout the country. A sample of 656 UMURENGE SACCO members was determined using Raosoft sample size calculator. Descriptive and inferential statistics were utilized to present and analyze data. The study results revealed that $75.8 \%$ of UMURENGE SACCO walks for less than an hour time to access financial services including opening bank account, deposit and withdrawals, savings, payments and credit. Nevertheless, less than 50\% of UMURENGE SACCO members are able to take loans. It is also worth noting that despite of low level of uptake, financial services of UMURENGE SACCO significantly contribute to socio-economic welfare of members. To achieve a wide level of uptake, financial service providers should ensure that services are tailored to customers' needs. Modern financial technologies should be leveraged on to achieve desirable level of convenience in service delivery.
\end{abstract}

Key words: Accessibility; Affordability; Convenience; Financial services; uptake 


\section{Introduction}

Every country is encouraged to undertake an inclusive growth strategy particularly financial inclusion, which enables each and every member of the society to link with the country's economic development agenda (Nayak, 2012). Indeed, financial inclusion is embraced as an important development priority by not only governments and their central banks but also the global development actors including the World Bank Development Group, United Nations Development Program, G20, and Alliance for financial inclusion. In the 2009 Pittsburgh Summit, G20 decided to make financial inclusion as one of its pillars. In October $2013 \mathrm{Jim}$ Kim, the president of the World Bank Group set forth the universal financial access goal by 2020 and asserted that "by 2020 adults should globally have access to an account or electronic instrument to store money, send and receive payments as the basic building block to manage their financial lives" (World Bank Group, 2015). With the efforts made, much has been done towards the global financial access. The number of adults excluded from formal financial services dropped by 20 percent to 2 billion in 2014, and 62 percent of adults from 51percent (in 2011) reported to have bank account in 2014 (World Bank, 2015).

The government of Rwanda did not lag behind in as far as the implementation of the universal financial access strategies is concerned. It has been actually proactive in its Vision 2020 implementation strategies. With vision 2020, Government of Rwanda aspiration is to fundamentally transform Rwanda into middle-income country by 2020 , thereby achieving per capita income of US $\$ 1240$ from US \$595 in 2011 (MINICOFIN, 2013). In the financial sector development strategy as a medium term implementation strategy of vision 2020, the Government of Rwanda seeks to achieve 20 percent, gross national savings and 30 percent, domestic credit to private sector as proportion of GDP by 2020 (MINICOFIN, 2013). Financial inclusion was therefore deemed necessary to move the poor out of poverty in sustainable manner. In fact, in 2008 after registering many microfinance institutions (MFIs) as commercial entities, Government of Rwanda in the December 2008 national dialogue meeting decided to establish at least one saving and credit cooperative (SACCO) at level of each administrative sector (UMURENGE) in the light of addressing excessive rate of financial exclusion. 416 SACCOs were established under the name of "UMURENGE SACCO" (MINICOFIN, 2009). By then, more than a half (52\%) of Rwandan adults was financially excluded.

With the establishment of UMURENGE SACCOs, much has been done for Rwanda financial inclusion. Finscope survey 2012 indicated that $91 \%$ of Rwandan adults live within 5kilometers radius of UMURENGE SACCOs. Finscope survey 2016 also indicates that 89 percent of adults of Rwanda are financially included. UMURENGE SACCOs significantly contributed towards Rwanda financial inclusion since 65 percent of adults are having/using formal financial services/ products offered by formal non bank financial institutions particularly Umurenge SACCOs and MFIs (Finscope , 2016). Nevertheless, plain access to financial services does not always imply full-fledged financial inclusion rather; access to financial services should be coupled with suitability, availability, affordability and actual use of financial services. Indeed, financial inclusion is achieved when there is access by enterprises and households to rationally priced and proper formal financial services that meet the needs of enterprises and households (Arif \& Aftab, 2017). Several studies conducted on the financial inclusion particularly in Rwanda focused on mere access (geographical access) 
to financial services, little or none has gone broader to uptake of financial services and related impact on the socio-economic welfare of beneficiaries. Thus, paper seeks to examine contribution of UMURENGE SACCOs towards financial inclusion in Rwanda considering accessibility, affordability and uptake of financial services.

\section{Financial inclusion defined}

There is no universal definition of the term "financial inclusion". Nevertheless, several scholars and development actors culminate on three main indicators such as accessibility, availability and usage of formal financial services for all segments of the population. Josiah \& Elizabeth ( 2012) stressed that financial inclusion is a process that ensures access to proper financial products and services needed by all segments of the community in general, and vulnerable groups including disadvantaged sections and low income earners in particular at affordable cost in a fair and transparent manner by regulated mainstream institutional financial services providers.

U.kama \& M. Adigun (2013) claimed that financial inclusion is a process or a situation which allows for ease of access to or availability of and usage of formal financial systems by members of the economy. They further emphasized that all the members of the economy should not have difficulty in opening bank account; can afford to access credit; and can conveniently, easily and consistently use financial system products and facilities without difficulty. In fact, in inclusive financial system people's incoming money is maximized while outgoing money is controlled through informed financial decision arising from basic financial literacy. Most recently, Arif \& Aftab (2017) also confirmed that financial inclusion is by, and large, the process of bringing financially excluded segments of the community into the sphere of formal financial system; inclusive financial system should ensure easy access, availability and usage of formal financial system for all members of an economy.

United Development Fund (2018) considers financial inclusion as means through which individuals and enterprises can access and use a range of appropriate and responsibly financial services offered in a well regulated environment. Furthermore, Indian committee on the financial inclusion viewed financial inclusion as a process of ensuring access to financial services and timely adequate credit where needed by vulnerable groups such as weaker sections and low-income groups at affordable costs (Rangarajan, 2008). This committee asserts that there should be a range of appropriate financial services including credit, savings, insurance and payment and remittances facilities available to every individual and enabling them to understand and access those services.

Commision Nacional Bancaria y de Varoles (CNBV,2009) affirmed that where there is financial inclusion, financial products and services have to be of high quality, affordable, sustainable and available within a physical proximity. Therefore, financial inclusion entails a universal and continuous access of population to diverse, adequate, and formal financial services as well as the possibility of using them according to prevailing needs; hence, enable them achieving desired development and welfare (CNBV, 2009). 
African Development Bank (AfDB) also denotes financial inclusion as all schemes designed in the light of making formal financial services available, accessible and affordable to all segments of the population by putting particular attention to specific sections of the population that have been historically marginalized by the formal financial sector either due to their income level and volatility, gender, location, type of activity or level of financial literacy (AfDB, 2013).

It is worth noting that all the definitions are keeping emphasizing that mere access to financial services does not imply comprehensive financial inclusion unless it is complemented by easy access, convenient and consistent usage of financial services. Thus, inclusive financial system should ensure accessibility, availability, affordability and proper usage of formal financial services by all members of the community.

\section{Principles and measurement of financial inclusion}

Simple access to a savings account and credits even when not operating does not mean financial inclusion. Given the key aspects of financial inclusion, Arunachalam R.S (2008) highlighted key conditions that should be met to have financial inclusion fully achieved. The first condition to achieve financial inclusion is that a range of financial products and services including opening bank account, savings, credits, payments/remittances, insurance and financial counseling/literacy that are customized, convenient and flexible for the use by all segments of the community should be designed by formal financial service providers. Secondly, such financial services/products together with their respective mechanisms should be affordable and competitive. Effective product cost is neither usurious nor perceived as very high (Arunachalam, 2008). Thirdly, financial literacy for poor should be emphasized to ensure that all people in the community are aware of the available financial services, their usage and thus enable them to make informed financial decisions. Furthermore, Delivery aspect should be structured in a manner that ensures there is simple and convenient delivery in such way that even people in remote areas are facilitated easily accessing financial services at lower costs. In this regard, documentation and other requirements for accessing financial services should be minimal and bother free considering literacy level of people who used to be excluded by formal financial system. Arunachalam (2008) ascertained that financial inclusion can also be achieved when clients are using products or services prevailed with the financial services providers. Thus, inclusive financial system should ensure that there is usage of saving products to promote economy; usage of transaction banking to manage remittances; usage of credit facilities to smoothen income volatility; usage of insurance services to protect against uncertainties. Last but not least, staff attitudes should be reflected in staff willingness to provide care to the client's welfare always; redness to deal with clients particularly the poor and illiterate in a timely, patient and concerned manner (Arunachalam, 2008).

Given definition and principles of financial inclusion, several scholars attempted to diagnose status of financial inclusion in different economies using three key indicators such as access to, usage and quality of financial services.

Access consists of the capacity those financial services providers have to provide formal financial services to traditionally disadvantaged people. Thus, while assessing access as a key 
dimension of financial inclusion potential barriers that financial services providers face in serving all segments of the community, and or that client are facing to financial services or products should be identified (World Bank, 2012). Clients should have sufficient physical proximity to access points including bank branches, agents, ATMs, and other outlets to enable them to easily choose a range of financial products/services even when they located in remote areas (Beck, Demirguc-Kunt, \& Matinez, 2007; Honhan, 2008; Sarma, 2008; Mersland \& R.Øystein, 2009; Chakravarty \& Pal, 2010; Arora, 2010; Gupte, Venkataramani, \& Deepa, 2012; Prathap, 2011).

Usage/uptake of financial products/services is reflected in ways through which clients use financial services including regularity and duration of financial product/service over time. This can be reflected in terms of average savings balances, number of transactions per account, number of electronic payments made, etc (World Bank, 2012). It worth noting that financial uptake is significantly influenced by quality of financial services. Quality of financial services implies ability of financial services/products to meet consumers' needs. This is measured by ascertaining the extent to which financial products and services match customers 'needs, the range of options available to customers and the consumers' awareness and understanding of financial products/services. Thus, proxy for quality as an indicator of financial inclusion is reflected in terms of convenience; product/service suitability; transparency; safety; consumer protection and financial literacy (World Bank, 2012).

\section{Methodology}

In this part, we discussed methodologies utilized to examine the extent at which UMURENGE SACCOs contributed in achieving accessibility, affordability and uptake of financial services in Rwanda. Therefore, population, sampling approach, and instruments and procedures for data collection, presentation and analysis applied are here below explained:

\subsection{Population and sampling}

As per financial stability report by Rwanda central bank (2015-2016), Rwanda counts 416 Umurenge Saccos throughout the country distributed over 30 districts, 4 provinces and Kigali City in accordance with local administration units mapping. One district from each province and Kigali city selected based on the level of remoteness. Remote areas were considered in the light of checking the essence of UMURENGE SACCOs. Gatsibo, Nyabihu, Rulindo, Gisagara and Gasabo districts were respectively selected from districts of Eastern province, Western province, North province, and South province and Kigali city. On the same criteria 2 UMURENGE SACCOs were selected from each selected district. Bumbogo and Rusororo from Gasabo district; Muhura and Murambi from Gatsibo District; Muganza and Mugombwa from Gisagara district; Bigogwe and Jenda from Nyabihu district; and Cyungo and Rukozo from Rulindo district. 10 selected UMURENGE SACCOs counts for 55,898 members out of which a sample 656 members was computed using Raosoft sample size calculator at 99\% confidence level. The number of respondents at each SACCO was proportionally determined as indicated in below table:

Table 1: Sample size calculation

\begin{tabular}{|c|c|c|l|r|r|}
\hline S/N & Province & District & SACCO & No. of Members & Members in sample \\
\hline 1 & EAST & GATSIBO & MUHURA & 4,821 & 57 \\
\hline
\end{tabular}




\section{$2^{\text {nd }}$ International Conference on}

\section{BUSINESS, MANAGEMENT \& ECONOMICS}

\begin{tabular}{|c|r|r|l|r|r|} 
& & & MURAMBI & 5,971 & 70 \\
\hline \multirow{2}{*}{2} & \multirow{2}{*}{ WEST } & \multirow{2}{*}{ NYABIHU } & BIGOGWE & 3,995 & 47 \\
\cline { 4 - 6 } & & \multirow{2}{*}{ RULINDO } & JENDA & 4,317 & 51 \\
\hline \multirow{2}{*}{3} & \multirow{2}{*}{ NORTH } & & CYUNGO & 5,421 & 63 \\
\cline { 4 - 6 } & & RUKOZO & 5,451 & 64 \\
\hline \multirow{2}{*}{4} & \multirow{2}{*}{ SOUTH } & \multirow{2}{*}{ GISAGARA } & MUGANZA & 6,251 & 73 \\
\cline { 4 - 6 } & & MUGOMBWA & 7,211 & 85 \\
\hline \multirow{2}{*}{5} & \multirow{2}{*}{ KIGALI CITY } & \multirow{2}{*}{ GASABO } & BUMOBOGO & 4,607 & 54 \\
\cline { 4 - 6 } & & & RUSORORO & 7,853 & 92 \\
\hline & \multicolumn{3}{|c}{ Total } & $\mathbf{5 5 , 8 9 8}$ & $\mathbf{6 5 6}$ \\
\hline
\end{tabular}

Source: Author's calculations

\section{2. $\quad$ Instruments and procedures for data collection, presentation and analysis}

This study focused data collected from demand side of financial inclusion using questionnaire. Researcher visited each selected Umurenge Sacco for 3 consecutive days and distributed questionnaire to members using first come, first served principle. For consistency purpose, number of targeted members at each Umurenge Sacco was divided into 3 equal subsample in such way that once targeted daily number were achieved, researcher stopped and turned up for the next day until data collection is completed. Data processing, presentation and analysis were conducted using STATA 12. Cross tabulation frequency analysis was used to determine the level of accessibility, affordability and uptake. Contribution of UMURENGE SACCOs financial services to members' socio-economic welfare was estimated using logistic regression model. Savings and credits/loan as key financial services offered by UMURENGE SACCOs were considered to be proxy for financial services while achieving food security, housing, health care and education were considered as proxy for socio-economic welfare achievement. Below equation was estimated:

Logit $=\ln \left(\frac{p}{1-p}\right)=\beta_{0}+\beta_{1} X_{1}+\beta_{2} X_{2}+\ldots+\beta_{k} X_{k}$

$\operatorname{logit}(\mathbf{p})=\log \left(\frac{\mathbf{p}}{\mathbf{1 - \mathbf { p }}}\right)$ gives the connection between $\mathbf{p}$ and linear predictors of the logistic regression model. $\beta=\left[\beta_{0}+\beta_{1}+\ldots+\beta_{k}\right]^{\prime}$ is the coefficients to be estimated and used to measures independent variables $\boldsymbol{X}_{\boldsymbol{j}}(\boldsymbol{j}=\mathbf{1}, \cdots, \boldsymbol{k})$ which most of cases categorical variables (Francois \& Augustin, 2016). For our study, explained variable is welfare achievement by Umurenge Sacco's members, while explanatory variables are savings and access to loan.

$$
p=\left(\mathbf{e}^{\beta_{0}+\beta_{1} X_{1}+\beta_{2} X_{2}+\ldots+\beta_{k} X_{k}}\right) /\left(1+e^{\beta_{0}+\beta_{1} X_{1}+\beta_{2} X_{2}+\ldots+\beta_{k} X_{k}}\right)
$$




\section{$2^{\text {nd }}$ International Conference on BUSINESS, MANAGEMENT \& ECONOMICS}

5. Results and Discussion

This part presents and discusses results from both descriptive and inferential analysis data collected from demand side of financial inclusion considering 10 Umurenge Saccos as early mentioned.

Figure 1: Financial products/services offered by UMURENGE SACCOs

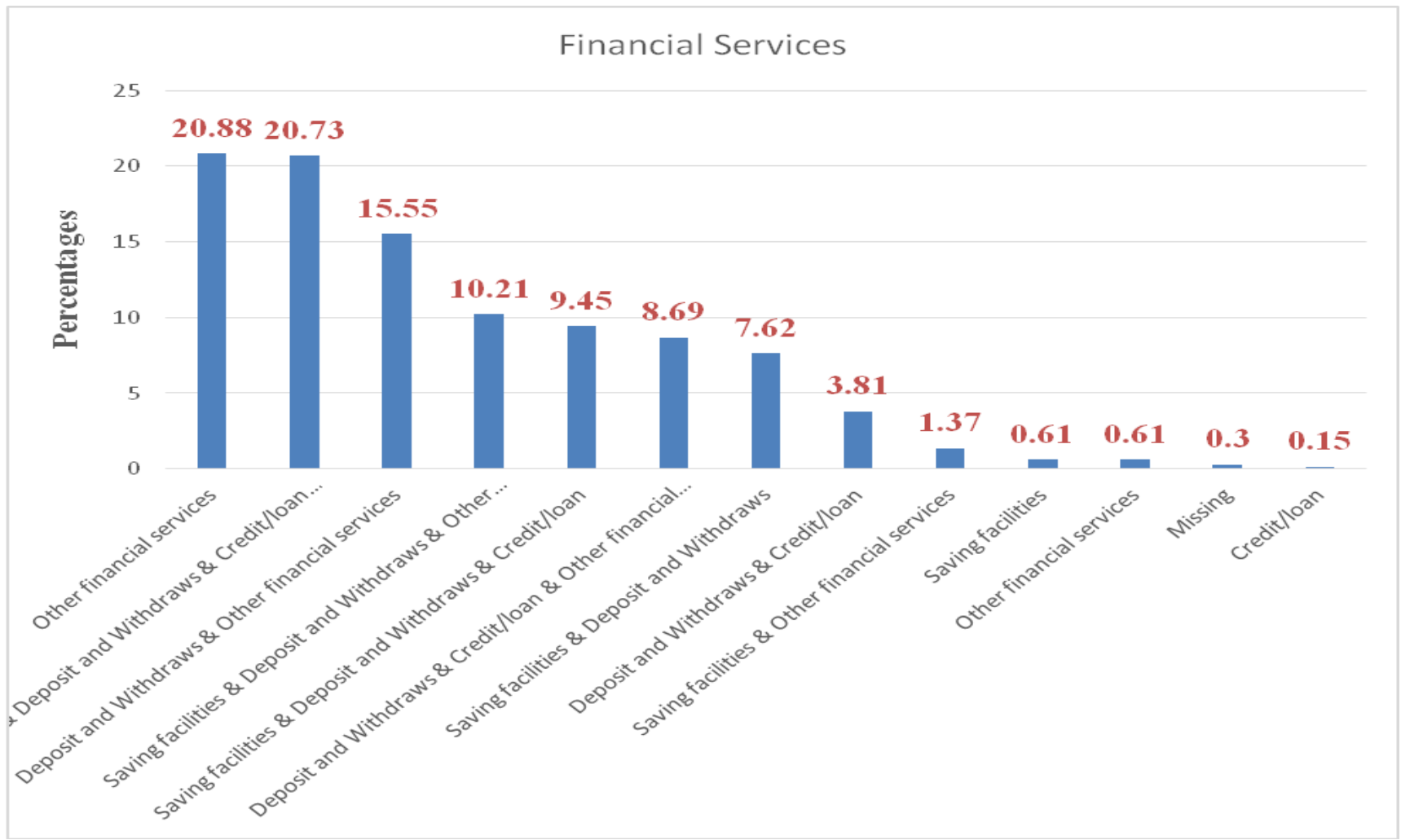

Source:Author's generated figure 


\section{$2^{\text {nd }}$ International Conference on BUSINESS, MANAGEMENT \& ECONOMICS}

From the data presented in figue 1 , it is realized that financial products/services supplied by UMURENGE SACCOs include transaction banking (deposits and withdrawals), savings, credits, payments and remittences, financial literacy/counseling and othe related services. But most commonly Umurenge Saccos financial services are transaction banking, savings and credits. This is indicated by the fact that combinations involving these services/products count for $78.21 \%$.

Table 2: Distribution of SACCO members according to travel time to access financial services

\begin{tabular}{|c|c|c|c|c|c|c|c|c|c|c|c|c|c|}
\hline $\begin{array}{c}\text { Time in } \\
\text { Minutes/UMU } \\
\text { RENGE_SAC } \\
\text { CO }\end{array}$ & $\begin{array}{l}0 \\
0 \\
0 \\
\sum_{0}^{0} \\
0\end{array}$ & 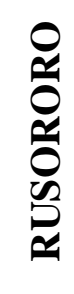 & 晃 & $\begin{array}{l}\sum^{\infty} \\
\sum \\
\sum \\
\sum\end{array}$ & $\frac{\mathbb{Z}}{\mathbf{Z}}$ & & לִ & $\underset{6}{\not}$ & 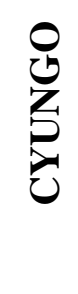 & 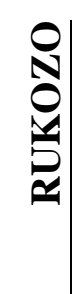 & $\stackrel{\frac{\sigma}{0}}{0}$ & 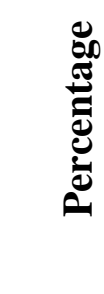 & 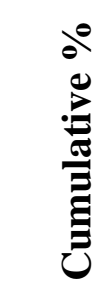 \\
\hline$<15$ & 6 & 38 & 8 & 5 & 9 & 11 & 20 & 13 & 18 & 13 & 141 & 21.5 & 21.5 \\
\hline $16-30$ & 11 & 33 & 7 & 12 & 14 & 13 & 20 & 9 & 25 & 11 & 155 & 23.6 & 45.1 \\
\hline $31-45$ & 10 & 6 & 11 & 9 & 13 & 21 & 4 & 6 & 8 & 10 & 98 & 14.9 & 60.1 \\
\hline $46-60$ & 12 & 12 & 10 & 14 & 11 & 13 & 2 & 11 & 5 & 13 & 103 & 15.7 & 75.8 \\
\hline $61-90$ & 3 & 1 & 12 & 11 & 5 & 16 & 1 & 7 & 3 & 10 & 69 & 10.5 & 86.3 \\
\hline 91-120 & 7 & 2 & 5 & 8 & 2 & 10 & 0 & 2 & 0 & 6 & 42 & 6.4 & 92.7 \\
\hline$>120$ & 5 & 0 & 4 & 9 & 19 & 0 & 0 & 1 & 4 & 1 & 43 & 6.6 & 99.2 \\
\hline Missing & 0 & 0 & 0 & 3 & 0 & 1 & 1 & 0 & 0 & 0 & 5 & 0.8 & 100 \\
\hline Total & 54 & 92 & 57 & 71 & 73 & 85 & 47 & 50 & 63 & 64 & 656 & 100 & \\
\hline
\end{tabular}

Source: Author's generated table

Reference made to information presented in table 2, 75.8\% of UMURENGE SACCOs members contacted walks for less than an hour time to access financial products/services indicated in figure1. This implies that being established at community based administrative unit Umurenge, UMURENGE SACCO as financial services provider in the aspect of 
financial inclusion model, it makes financial services available even to a relatively remote area. The higher the proximity of financial services supplier to customers, the more financial inclusion is achieved in terms of accessibility of financial services. Hence, the establishment of UMURENGE SACCO achieved accessibility of financial services in Rwanda.

Table 3: Uptake of Key UMURENGE SACCO Financial services/products

\begin{tabular}{|c|c|c|c|}
\hline savingl & $\begin{array}{r}\text { loan } \\
0\end{array}$ & $s$ & Total \\
\hline 0 & $\begin{array}{r}136 \\
73.12\end{array}$ & $\begin{array}{r}50 \\
26.88\end{array}$ & $\begin{array}{r}186 \\
100.00\end{array}$ \\
\hline$\perp$ & $\begin{array}{r}191 \\
47.87\end{array}$ & $\begin{array}{r}208 \\
52.13\end{array}$ & $\begin{array}{r}399 \\
100.00\end{array}$ \\
\hline Totall & $\begin{array}{r}327 \\
55.90\end{array}$ & $\begin{array}{r}258 \\
44.10\end{array}$ & $\begin{array}{r}585 \\
100.00\end{array}$ \\
\hline
\end{tabular}

Source: Author's generated table

As per the designation of UMURENGE SACCO, key financial services are credits and savings. From the information captured in table 3, less than $50 \%$ of contacted SACCO members were able to access loans, while $55.90 \%$ saved with their respective UMURENGE SACCO. It is worth noting that having saved with SACCO, Members are more likely to access loan thereof.

Table 4: Key reasons for not accessing UMURENGE SACCO Loans

\begin{tabular}{|c|c|c|}
\hline Reasons & Frequency & Percentage \\
\hline Don't have repayment capacity & 108 & 34.50479 \\
\hline I am not a need of loan & 103 & 32.90735 \\
\hline don't meet collateral requirement & 32 & 10.22364 \\
\hline Interest charged is too high & 26 & 8.306709 \\
\hline Application rejected & 14 & 4.472843 \\
\hline Simply I fear loan & 8 & 2.555911 \\
\hline Others & 22 & 7.028754 \\
\hline Total & 313 & 100 \\
\hline
\end{tabular}

Source: Author's generated table

From the information presented in the above table, it is indicated that members of UMURENGE SACCOs are not taking loans due to lack of financial capacity to repay back loans (34.5\%); their financing need is covered elsewhere (32.9\%); not meeting collateral requirements (10.22\%); high interest cost (8.3\%); Application rejection (4.5\%) and simply fearing taking loans. Though considerable number of SACCO members is served for credit elsewhere particularly in their village 
rotating credit and savings (tontines), SACCO loans are relatively costly to induce members taking them.

Table 5: Contribution of UMURENGE SACCOs Financial products/services to Members welfare

\begin{tabular}{|l|l|l|l|l|l|l|}
\hline Welfare & Odds Ratio & Probability & Std. Err. & $\mathrm{z}$ & $\mathrm{P}>\mathrm{z}$ & [95\% Conf.Interval] \\
\hline 1.saving1 & 2.129278 & 0.68043747 & 0.4304377 & 3.74 & 0.000 & {$[1.432717,3.164495]$} \\
\hline 1.loan_access & 4.167276 & 0.80647444 & 0.7618666 & 7.81 & 0.000 & {$[2.912289,5.963071]$} \\
\hline cons & 0.2595116 & & 0.047222 & -7.41 & 0.000 & {$[0.1816636,0.3707198]$} \\
\hline
\end{tabular}

Source: Author's generated table

Given logit linear regression model estimated and presented in table5, it is indicated that SACCO member who accessed to loan is about 4 times more likely to achieve welfare compared to SACCO member who didn't access to loan, other variables held at constant value $(\mathrm{OR}=4.16, \mathrm{P}=0.8, \mathrm{P}>\mathrm{z}=0.000)$ on the other hand, member who saved with UMURENGE SACCO is about 2 times more likely to achieve welfare compared to a member who did not save $(\mathrm{OR}=2.13, \mathrm{P}=0.68 ; \mathrm{P}>\mathrm{z}=0.000)$.

\section{Conclusion}

From the findings presented and discussed above, it is generally revealed that establishment of UMURENGE SACCOs contributed in achieving financial inclusion in Rwanda by making basic financial products/services including transaction banking, savings, credits, payments and remittances and other services proximate to people who may even be previously not served due to being located in a remote area. On the aspect of uptake of financial services, findings revealed that level of usage is still questionable whereby, less than 50\% SACCO members took loans compared to $55.9 \%$ who saved. It was also noted almost of those reported savings are counted among usual deposits (current account) not term deposit (Savings). Nevertheless, considering basic needs required to have been achieved like food security, household housing in good reasonable condition, ability to meet health care and education requirements, it was generally revealed that accessing to financial services of UMURENGE SACCO significantly contributed to members' socio economic welfare. Therefore, to achieve desirable level of financial inclusion, UMURENGE SACCOs as financial service provider at community based level, should ensure that a range of financial products/services designed is such way that they tailored to suit customers' needs. To ensure that service delivery is conveniently achieved financial technologies including networking of 
UMURENGE SACCOs across country should also be leveraged on in the light of wide accessibility and uptake.

\section{References}

1. AfDB. (2013). Financial Inclusion in Africa. Tunis: African Development BankAfrican Development Fund.

2. AFI. (2011). Defining and Measuring Financial Inclusion. Tunis: African Development BanK.

3. Arora, R. U. (2010). Measuring Financial Access. Griffith University.

4. Arunachalam, R. S. (2008). Scoping Paper on Financial Inclusion:Consideration and Recommendations for UNDP. India : United Nations Development Programme-India.

5. Back, T., Demirguc-kunt, A., \& Patrick, H. (2009). Access to Finance and Development:Theory and Measurement. World Bank Research Observer .

6. Beck, T., Demirguc-Kunt, A., \& Matinez, P. m. (2007). Reaching out Access to and use of banking services accross countries. Journal of Financial Economics , 234-266.

7. Chakravarty, S. R., \& Pal, R. (2010). Measuring Financial Inclusion: An Axiomatic Approach. Mumbai: Indira Gandhi Institute of Development Research.

8. Demirguc-Kunt, A., Klapper, L., Ansar, S., \& Jake, H. (2017). The Globol Findex Database. Washington DC 20433: World Bank.

9. Diamond, W., \& Ragan, G. R. (2000). A Theory of Bank Capital. Journal of Finance , 2431-2465.

10. Garg, S., \& Agarwal, P. (2014). Financial Inclusion in India: Review of Initiatives and Achievements. Journal of Business and Management, 52-61.

11. HM Treasury . (2004). Promoting Financial inclusion . Norwich : HM Reasury .

12. Honhan, P. (2008). Cross-Country variation in household access to financial services . Journal of Banking and Finance .

13. Josiah, A., \& Elizabeth, K. (2012). Financial inclusion and Financial sector stability with reference to Kenya: A Review of Literature. Journal of Applied Finance \& Banking , 95-120.

14. Kadama, U., \& Adigun, M. (2013). Financial Inclusion in Nigeria: Issues and Challenges. Abuja: Central Bank of Nigeria.

15. Kuznets, S. (1955). Economic Growth and Income Inequality . The American Economic Review , 1-28.

16. Mandira, S. (2008). Index of Financial Inclusion. Indian Council for Research on International Economic Relations .

17. Mersland, R., \& R.Øystein, s. (2009). Performance and Governance in Microfinance Institutions . Journal of Banking and Finance , 93-120.

18. Nawaz, T. (2018). Lifting the Lid on Financial Inclusion: Evidence from Emerging Economies. International Journal of Financial Studies .

19. Nawaz, T. (2018). Lifting the Lid on Financial inclusion: Evidence from Emmerging Economies. International Journal of Financial studies .

20. Nenston, J. G., \& Smith, W. C. (1976). A Transactions Cost Approach to the Theory of Financial Intermediation. Journal of Finance, 215-231. 


\section{$2^{\text {nd }}$ International Conference on BUSINESS, MANAGEMENT \& ECONOMICS}

21. O.Oyelamani, L., M.Saibu, O., \& S.Adekunle, B. (2017). Determinants of Financial inclusion in Sub-Sahara African Countries. Coventant Journal of Business and Social Sciences , 104-116.

22. Seman Abu, J. (2016). Financial Inclusion: The Role of Financial System and other Determinants. PhD Thesis. Salford: Salford Business School.

23. The People's Bank of China. (2018). Towards Universal Financial Inclusion in China:Models, Challenges and Global Leassons. Beiging: The People's Bank of China and World Bank Group.

24. World Bank . (2013). Financial Inclusion in Brazil: Building on Success. World Bank.

25. World Bank. (2018). 2018 The Little Data Book on Financial Inclusion. Washington DC 20433: World Bank.

26. World Bank. (2018, October 2). Financial inclusion:Overview. Retrieved February 20, 2019, from World

https://www.worldbank.org/en/topic/financialinclusion/overview 